\title{
Kulturowe ramy zachowań społecznych w reportażu Nie ma Mariusza Szczygła (psychologia międzykulturowa w badaniach literaturoznawczych)
}

\section{Literaturoznawstwo jako kulturowa podróż: wprowadzenie}

Ryszard Kapuściński, niekwestionowany autorytet polskiego reportażu, w zakończeniu Podróży z Herodotem zapisuje konstatację, którą można uznać za niezwykle cenną wskazówkę dla badacza literatury ukierunkowanego na poszukiwanie zależności pomiędzy zachowaniami społecznymi a kreacją artystyczną. W postawie starożytnego historyka i podróżnika reporter dostrzega bowiem pasję poznawania, której istotą jest otwartość na to, co inne:

I Herodot z zapałem i zachwytem dziecka poznaje swoje światy. Jego najważniejsze odkrycie - że jest ich wiele. I że każdy jest inny. Każdy ważny. I że trzeba je poznać, bo te inne światy, inne kultury to są zwierciadła, w których przeglądamy się my i nasza kultura. Dzięki którym lepiej rozumiemy samych siebie. I dlatego Herodot, dokonawszy tego odkrycia, odkrycia kultury innych, jak zwierciadła, w którym możemy się przejrzeć, aby samych siebie lepiej zrozumieć, każdego poranka, niezmordowanie, znowu i znowu wyrusza w swoją podróż.

(Kapuściński, 2004)

Kontakty z przedstawicielami różnych kultur są integralną częścią naszego życia, a tym samym zmuszają do podjęcia refleksji nad stanem własnej 
świadomości, będąc niejako lustrem, w którym się przeglądamy i dzięki któremu dostrzegamy kwestie, które ujawniają się dopiero w sytuacji zderzenia $\mathrm{z}$ „innym”. Tę prawidłowość dostrzegł już Herodot, jednak w sytuacji stopniowego zagęszczania się siatki światowych połączeń (Boski, 2010: 11) wydaje się, że postawa dziecięcej otwartości na świat jest warunkiem sine qua non zrozumienia rzeczywistości kulturowej, w jakiej obecnie się znajdujemy. Spotkania takie to bowiem doświadczenia jednocześnie „budujące i szokujące, twórcze i będące powodem poważnych trudności; ważne dla naszego życia” (Boski, 2010: 11). To swoiste zapoznanie się, jak pisze Richard Rorty, „z tak wielką różnorodnością istot ludzkich jak to tylko możliwe" (Rorty: 15), uczy patrzenia na świat oczyma innego i pozwala zarazem na odnajdywanie drogowskazów (Blumenberg, 2017), na budowanie specyficznej sieci odniesień (Blumenberg, 2009: 144) oraz na łączenie elementów mozaiki „cytatów kultury” w całość (Steiner: 26).

Dzięki tak zorientowanemu podejściu zakodowane w literaturze znaki kultury można rozumieć przede wszystkim jako produkt myślenia kolektywnego, którego efektem jest określony obraz świata zależny od „małej kultury”, w której obraca się jednostka - także sam badający. Jest to także kusząca perspektywa badawcza, bo w jej naturę wpisana jest epifaniczna zdolność języka, dzięki której można eksplorować kulturę. Paweł Boski, podobnie jak Herodot, zauważa bowiem, że doświadczenie i wskazówki poruszania się po świecie zdobywamy wraz z kulturowymi podróżami, które, jak sądzę, może nam zagwarantować proces lektury:

Dziś nie można już być „odkrywcą” nieznanych lądów i zamieszkujących je „egzotycznych” ludów. Świat jest wciąż jednak pełen różnych przepisów na życie, które można poznać, będąc wrażliwym kulturowo podróżnikiem.

(Boski, 2010: 19)

Literatura jest bowiem szczególnym rodzajem „lustra”, w którym przegląda się każdy, kto świadomie wchodzi w nową kulturę. Umożliwia nakreślenie zewnętrznego świata na podstawie jego obrazów odbitych w tkance literackiej, pozwala dokonać przekładu wzajemnego, a także skutecznie wejść w dialog międzykulturowy, co zdaniem Tamary Czerkies, przedstawicielki glottodydaktyki polonistycznej (dziedziny nauki bazującej ostatnio dość wyraźnie właśnie na założeniach psychologii międzykulturowej), respektuje potrzebę kreatywnego 
podejścia do poznawanej kultury i języka w procesie negocjowania znaczeń (Czerkies, 2019: 7). Ten swoisty dialog rodzący się w spotkaniu z teksem, nazywany także dyskursem (Czerkies, 2012), warunkuje świadome użytkowanie języka oraz wejście w treshold level, czyli w biegłość, która obejmuje nie tylko znajomość systemu, lecz także rozumienie zwyczajów społecznych (social conventions), rytuałów społecznych (social rituals) oraz doświadczeń uniwersalnych (universal experiences). Kultura narodowa jest bowiem „dynamicznym układem, gdyż stanowi rezultat twórczych i odbiorczych działań ludzi” (Kłoskowska, 1996: 35), a zatem także - metaforycznym glinianym kubkiem (Benedict, 1966), który decyduje o znaczeniu pojedynczych elementów w niego włożonych. Język, sztuka, nauka, historia i obyczaje są tym samym specyficznymi „wycinkami” systemów kulturowych powiązanych związkami syntagmatycznymi (Kłoskowska: 38).

Proces czytania przez obcokrajowców jest więc wskazówką dla literaturoznawcy, bo jego definicja, zawarta ad exemplum w anglojęzycznej publikacji The Ways of Reading. Advanced Reading Skills for Students of English Literature:

How does your reading proceed? Clearly you try to comprehend, in the sense of identifying meanings for individual words and working out relationships between them, drawing on your implicit knowledge of English grammar. If you are unfamiliar with words or idioms, you guess at their meaning, using clues presented in the context (as possibly with 'the right hand of friendship'). On the assumption that they will become relevant later, you make a mental note of discourse entities such as 'my relatives in England' and 'John Herncastle', as well as possible links between them. You begin to infer a context for the text, for instance by making decisions about what kind of speech event is involved: who is making the utterance, to whom, when and where?

(Montgomery i in., 1992: 7) ${ }^{1}$

1 „Jak przebiega proces czytania? Po prostu starasz się zrozumieć, to jest zidentyfikować poszczególne słowa i dostrzec relacje zachodzące pomiędzy nimi, czerpiąc wiedzę z angielskiej gramatyki. Jeśli nie znasz słów lub idiomów, odgadujesz ich znaczenie, używając wskazówek zawartych w kontekście (możliwie wykorzystując tę „pomocną dłoń”). Zakładając, że staną się one później istotne, tworzysz mentalną notatkę jednostek dyskursywnych, swego rodzaju „językowych krewnych”, a także sieć możliwych powiązań występujących między nimi. Zaczynasz wnioskować na podstawie kontekstu tekstu, na przykład podejmujesz decyzję o tym, jaki rodzaj wystapienia jest powiązany z danym wydarzeniem: kto to wypowiada, do kogo, kiedy i gdzie?” [tłum. M.U.] 
wpisuje się w dyskusję nad zagadnieniem odpowiedzialnej lektury, o której pisał między innymi Michał Paweł Markowski w kontekście „zwrotu etycznego” (Markowski, 2000). Literatura jest bowiem miejscem, w którym spotykają się ze sobą rozmaite punkty widzenia, a także „pozostatości, rudymenty” obserwowane w trakcie drogi „od mitu do logosu” (Blumenberg, 2017: 11). Do ich zrozumienia konieczna jest zatem nie tylko language avareness (świadomość językowa), lecz także critical language avareness (krytyczna świadomość językowa) (Fairclough: 224-227). Czytanie jest wszakże rodzajem quessing game („gry w odgadywanie”), która polega na procesie łączenia wyselekcjonowanych znaków językowych z własnym doświadczeniem (Goodman: 16). Oznacza to odszyfrowywanie ukrytych w języku sensów, czyli stale używanych figur, często aktywowanych w ramach analogii, które jednocześnie są obiektywami, przez które patrzymy na świat, czy też opisywany przedmiot (Abrams: 41).

\section{Psychologia historyczno-kulturowa a literaturoznawstwo}

Psychologia międzykulturowa i psychologia indygeniczna, jak zaznaczono wcześniej, są dziedzinami nauki chętnie wykorzystywanymi, nie bez racji zresztą, przez glottodydaktykę. W nauczaniu danego języka jako obcego coraz bardziej powszechne stają się bowiem metody takie, jak na przykład trening akulturacyjny i międzykulturowy, których zadaniem jest uwrażliwienie zarówno nauczyciela, jak i uczącego się na ważkie znaczenie kompetencji kulturowej w nauczaniu i uczeniu się języków. Teoretyczne i praktyczne zdobycze tych dwóch subdyscyplin psychologii głównego nurtu śmiało można przełożyć także na klasyczne literaturoznawstwo. To teza tym bardziej zasadna, że psychologie międzykulturowa i indygeniczna notują w pewnym stopniu zbliżone do nauki o literaturze problemy teoriopoznawcze. Zarówno w psychologii historyczno-kulturowej, jak i w literaturoznawstwie, stale powraca problem dychotomii myślenia o człowieku, na którego duszę składa się tak „realność” jego osoby, jak i jego mityczna tożsamość, której istotę trudno opisać przy pomocy czysto empirycznych narzędzi dawczych. Psychologia międzykulturowa, podobnie więc jak literaturoznawstwo, nieustannie poszukuje swojej drogi metodologicznej, która pozwalałaby na to, by analogony, przez które człowiek widzi świat, ująć 
w empirycznym, niejako „udowadnialnym” opisie. Psychologia historyczno-kulturowa, której częścią są wspomniane psychologia międzykulturowa i indygeniczna, jest nastawiona bowiem nie tylko na obiektywny pomiar i wyjaśnienie, lecz przede wszystkim na opis, zrozumienie, relatywizm, subiektywizm oraz podmiotowe doświadczenie w świecie kolektywnych relacji (Pankalla, Kośnik: 70). Myślenie, w tym specyficznym układzie odniesień, rozumie się bowiem przede wszystkim jako czynność zbiorową, której produktem jest określony obraz świata zależny od „małej kultury”, w której obraca się jednostka - a także sam badający (Fleck, 1896). Naukowiec nieświadomie przypisuje zaobserwowanym zjawiskom i obiektom własną perspektywę, a tym samym, jak dowodzą Pankalla i Kośnik, psychologia międzykulturowa i indygeniczna, będące dyscyplinami skierowanymi w stronę lokalności, mogą rościć sobie prawo do najpełniejszej adekwatności opisu, gdyż:

Człowiek dokonuje uwarunkowanej kulturowo interpretacji własnych doświadczeń, na podstawie której podejmuje określone działania stanowiące następnie przedmiot analizy badacza w celu rekonstrukcji znaczeń.

(Pankalla, Kośnik, 2018: 77)

W psychologii tego nurtu chodzi zatem o uchwycenie lokalnej mentalności użytkowników danej kultury przy zachowaniu maksimum obiektywności, możliwej dzięki zanurzeniu badacza w kulturę, którą opisuje. Tak jak psychologie międzykulturowa i indygeniczna realizują swoje badania w analizie specyficznych pojęć, przekonań i praktyk kulturowych w celu zrozumienia funkcjonowania człowieka w kontekście kulturowo-historycznym (Pankalla, Kośnik: 77), tak samo czyni to teoria literatury. W badaniu literatury, zwłaszcza współczesnej, należałoby więc uwzględnić i zgłębić wiedzę na temat unikatowej kompozycji każdego systemu kulturowego, historycznych źródeł i ciągłości kulturowej, trzonowych i peryferyjnych wymiarów kultury, idealnego i realnego poziomu jej funkcjonowania oraz wspólnych wzorców tożsamościowych i pewnych wewnętrznych sprzeczności (Boski, 2010 :371). W przypadku próby opisania polskiej literatury w tego typu ujęciu trzeba ponadto pamiętać o pułapce, jaką zastawiają na badacza powierzchowne opracowania historycznych warunków tworzenia się profilu polskiej kultury. Wielu bowiem naukowców, czy to psychologów, czy literaturoznawców, jak zauważa Paweł Boski, sprowadza specyfikę 
regionu Europy Środkowo-Wschodniej do doświadczeń i konsekwencji komunizmu, zapominając o przeszło pięciusetletniej perspektywie (Boski, 2010: 373). Tymczasem historyczna analiza polskiej kultury, wraz z opisem trzystu lat zagrożeń, utrat i niepewnej suwerenności, ma swoje konsekwencje, które objawiają się w postaci swoistego humanizmu, przypisywania wysokiego statusu kategorii kobiecości, specyficznego traktowania rodziny jako podstawowej grupy tożsamościowej, personalizacji życia publicznego, antymaterializmu, słabych kompetencji pragmatycznych w zakresie ekonomii, deficycie orientacji przyszłościowej, delegitymizacji władzy jako jednostki niegodnej zaufania czy silnej identyfikacji z symboliką narodową przy słabym utożsamianiu się z państwem (Boski, 2010: 381). Te specyficzne wymiary polskiej kultury można natomiast wyłuskać z twórczości literackiej. W niniejszym artykule jako przykład posłużą fragmenty nagrodzonego Literacką Nagrodą Nike reportażu Mariusza Szczygła Nie ma. Oprócz tego bowiem, że Nie ma to opowieść o braku, który wraz z jego uświadomieniem sobie otwiera na świat i wskazuje rytmikę życia (Szczygieł: 309), to jest to także obraz stosunków międzyludzkich, swoiste studium budowania autodefinicji człowieka, stykającego się z doświadczeniem życia i śmierci, radości i smutku, swojego i obcego... - zatem z wszelkimi formami tytułowego „nie ma”.

\section{Czesi sq weseli, Polacy sq smutni - tożsamość kulturowa Polaków w zderzeniu z ,innym” na przykładzie Nie ma Mariusza Szczygła}

Działalność reporterska Mariusza Szczygła, w polu której znajduje się między innymi silne zainteresowanie kulturą Czech i poniekąd zderzanie jej z kulturą Polski, wpisuje się w tego typu badania dość wyraźnie. Oto bowiem na kartach swoich reportaży Szczygieł kreśli tożsamość kulturową, która zakłada „istnienie zewnętrznej, niezależnej od jednostki sfery symboliki i wartości” (Boski, 2010: 473) oraz stanowi rodzaj „relacji człowieka do tych elementów w postaci subiektywnej wiedzy/kompetencji oraz kateksji afektywnej (przywiązania) i kompetencji behawioralnych" (Boski, 2010: 473). Co prawda Szczygieł w reportażu Nie ma stawia przede wszystkim na problematykę tożsamości jednostkowej i relacje między tym, co osobiste a społeczne w autodefinicji człowieka (Boski, 
2010: 470), jednak to właśnie w tym zamyka rys całej grupy społecznej. Maria Jarymowicz zaobserwowała bowiem, że w każdym człowieku współwystępują dwie siły: dążność do odrębności oraz łączności z innymi w ramach wspólnych kategorii (Jarymowicz, 1992: 213-275). Jednostkowe losy czeskiej poetki, ukraińskiego żołnierza, polskiej księgowej i ojca autora są więc obrazem konstrukcji teoretycznej, w której różne struktury ja wiążą się z przeciwstawnymi w stosunku do niego mechanizmami odnoszenia się do innych ludzi (Boski, 2010: 470). Obrazem tej teoretycznej konstrukcji jest fragment rozdziału Jerzy Szczygiet w Pradze, w której reporter relacjonuje postawę ojca wobec Czechów, naznaczoną zarówno stereotypem, jak i ujmowaniem rzeczywistości innych ludzi zależnie od własnego punktu widzenia:

Tata jest nieprawdopodobnie rozmowny, więc namawia mnie, żebym zagadywał Czechów. Tylko pamiętaj, Czechów, inni nie są tak ciekawi. Zagaduję więc przy obiedzie w restauracyjnym ogródku pulchnego szatyna z rudym zarostem. Jan, menadżer w jakimś hotelu. Spytaj go, mówi tata (Jezus, będę na starość zachowywał się identycznie jak on albo bardziej, już to po sobie widzę!), więc spytaj go jacy są Czesi. Mam go tak normalnie zapytać, jacy są Czesi, skoro go nie znam? No tak, bo ja chcę wiedzieć, przecież czwarty raz jestem w Pradze, a jeszcze nie zapytałem. Pytam więc, a ów Jan, lat 34, mówi, że Czesi są okropni i on ich nie lubi. [...] Mówi, mówię tacie, że Czesi są smutni. Obojętni na świat i zamknięci w sobie. No nie! Tata protestuje, są bardzo weseli, na przykład ten kapelusz kupiłem za drugim razem, gdy byliśmy w Pradze, u Wietnamców na ulicy Na Veseli, co znaczy $\mathrm{Na}$ Wesołym, a gdzie w Polsce jakaś ulica tak się nazywa, no gdzie? U nas to smutno jest i Rydzyk. Poza tym raz mieszkaliśmy na wakacje u pana Milana i to było między Na Veseli a na Lepsim. No już lepiej nie można, że wesoło, i lepiej.

(Szczygieł, 2018: 42-43)

Nabycie przez bohatera pozytywnego traktowania „obcych”, które oznacza dojrzałość do decentracji oraz umiejętnosśc do ujmowania rzeczywistości w sposób niezależny od własnego punku widzenia, możliwe jest dopiero wtedy, gdy dojdzie do procesu indywidualizacji, bo jak twierdzi Boski, „tylko wtedy [...] jednostka jest w stanie rozumieć takiego odmiennego człowieka, przyjąć jego perspektywę" (Boski, 2010: 470). Podobnie rzecz dzieje się w przypadku Czecha Jana, który wyraża swoją opinię na temat języka polskiego: 
A ja powiem panom szczerze, mówi Jan, że nie lubię słuchać polskiego, strasznie miękki ten język macie, jakby dziecko sepleniło, nasza ciestina to jest jednak najtwardszy ze słowiańskich języków, prawie tak twardy jak niemiecki.

(Szczygieł, 2018: 44)

Zachowanie zarówno Jerzego Szczygła, jak i Jana, jest obrazem depersonalizacji charakteryzującej zachowania na poziomie międzygrupowym (Boski, 2010: 465-466). Obaj bohaterowie są przedstawicielami określonych grup, które determinują ich oczekiwania. Czech wpisuje się swoją postawą w model postawy poszukiwania pozytywnej tożsamości społecznej, wywołującej pęd ku wyższości grupy własnej. Dokonując charakterystyki języków, Jan dąży do podwyższenia poczucia własnej wartości, którą można za Henrim Tajfelem zapisać w postaci sekwencji: kategoryzacja społeczna - tożsamość społeczna porównania społeczne - pozytywne wyróżnienie grupy własnej (Boski, 2010: 466). Postawa Jerzego Szczygła wpisuje się z kolei w drugi biegun zachowań na poziomie międzykulturowym. W przytoczonym cytacie zobrazowane jest bowiem odejście od stronniczości faworyzującej członków własnej grupy na rzecz swoistego braku lojalności wobec niej. Bohater wpada zarazem w pułapkę stereotypu, jak i autostereotypu. Przypisuje bowiem reprezentantom grup jednostkowe cechy osobowościowe, które można zapisać za pomocą uproszczonej formuły: „Czesi są weseli, Polacy są smutni”.

Spotkania z ,innym” to jednak nie tylko zapis relacji na poziomie międzykulturowym, które w pierwszym swym znaczeniu można pojmować jako interakcje zachodzące $\mathrm{w}$ kontaktach $\mathrm{z}$ przedstawicielami innych narodów. To także zderzenia z tym, co w znaczący sposób odbiega od wzorcowego modelu zachowania, albo w sposób wyraźny narusza poczucie kulturowego komfortu. Tożsamość kulturowa Polaków, oparta w dużym stopniu na tradycjonalizmie kulturowym, może - jak twierdzi Paweł Boski - powodować niechęć wobec odmienności wobec przejawów zachowań odbiegających od przyjętych praktyk (Boski, 2010: 485). Odejście od powszechnie uznanych za dobre wartości wiąże się zaś z określonym stosunkiem wobec praktyk i ludzi wykraczających poza pewne kanony. Szczególnym tego przykładem jest problem wpływu religijności na reakcje na „inne”. Zdaje się, że i ten problem zderzenia z owym „innym” w swoim literackim reportażu realizuje Szczygieł. W rozdziale Wiele męskich scen, opisującym działalność rzeźbiarza Tomasza Górnickiego, którego twórczość 
budzi wśród Polaków niemałe kontrowersje, a ściślej - we fragmencie Jezus po raz pierwszy, odzwierciedla się konstrukt, wedle którego religijne przekonania Polaków wpływają na to, jak podchodzą do innej niż obiegowa realizacji wizerunku Jezusa. Oto bowiem reakcją na umieszczenie przez artystę figur Jezusa przy budce z kebabem w Częstochowie, czy też na Trasie W-Z w Warszawie, jest wyrzucanie lub nawet niszczenie wizerunków odbiegających od powszechnie uznawanej za właściwą normy. Dla artysty jednak, co znamienne, tego typu praktyki to nie akt wandalizmu, ale dialog (Szczygieł: 177). Dlatego dialog, że jest to właśnie sposób radzenia sobie społeczności z tym, co kulturowo odbiega od normy. Specyficzna i powtarzająca się reakcja na to, co wykracza poza kanon wiary i pochodną od niej moralność (Boski, 2010: 485) pokazuje bowiem, że część Polaków z „innym” radzi sobie właśnie przez wyparcie.

Stosunek do inność dotyczy jednakowoż nie tylko kwestii religijności, lecz także innych wartości. Przykładem tego typu odpowiedzi na „obce” w reportażu Szczygła jest świadectwo powstawania i funkcjonowania w przestrzeni miejskiej rzeźby Przepraszam to za mato, przez Górnickiego usytuowanej pod mostem w Częstochowie, w pobliżu Dworca Kolejowego Stradom:

Znasz moje rzeźby i wiesz, że z miejsc, w których je instaluję, są kradzione czy niszczone, ale tu z chłopcem stało się coś gorszego. Wyjątkowo zabezpieczyłem tę rzeźbę. Wykopałem dół, wstawiłem blok betonowy, połączyłem chłopca drutami z tym blokiem, zalałem gipsem. Ktoś go zniszczył, ale nie że go przewrócił, wyrwał i zabrał. Ktoś go zmasakrował. Prętem? Cegłą? Całe ciało jest rozbite w mak. Głowa urwana. Ktoś wpadł w szał. Trzeba było naprawdę się postarać, żeby go tak pokawałkować. No i co sobie ten ktoś pomyślał? Daję ludziom rzeźbę o agresji, a ona spotyka się z agresją. Nie mógł tematu tego obrazu dźwignąć́? Trauma czy głupota? A jeśli jest tak głupi, żeby rzeźbę rozpieprzyć, to może jest też tak głupi ... [...].

(Szczygieł, 2018: 187)

Ta relacja wskazuje przede wszystkim na problem agresji, czy też społecznego przyzwolenia na przemoc, jednak pokazuje także, jak kulturowo radzimy sobie z tym, co jest tematem tabu. Można zatem skonstatować, że to, co odbiega od norm, od szeroko pojętego kanonu kulturowego, a także to, co wiąże się ze stereotypami i zaprogramowanymi niechęciami wobec odmienności, decyduje o sposobach radzenia sobie jednostek z trudnymi doświadczeniami. Nie zawsze jednak ma to znaczenie pejoratywne. Konsekwencje depersonalizacji, 
stereotypizacji i skrajnych reakcji wobec „innego” w przeważającej większości mają oczywiście odcień negatywny, czego przykładem, prócz wyżej opisanej postawy wobec instalacji Górnickiego, jest przypadek Ewy T., bohaterki fragmentów Nie ma: Śliczny i postuszny oraz Reportażu życie po życiu. Jej życie, jak sam Szczygieł zauważa, było bowiem wypadkową postawy zarówno kata, jak i ofiary rodziców, czy też tradycji swojej rodziny i źle pojętej religijności (Szczygieł, 2018: 292). Te zjawiska jednak są również nieuchronne. „Tożsamość kulturowa - pisze Boski - nie daje gwarancji pokojowej koegzystencji dla ludzi różnego pochodzenia" (Boski, 2010: 491). Dlatego, choć wszelkie depersonalizacje mają z reguły konotacje pejoratywne, to jednocześnie bywają też pewnego rodzaju lustrem kulturowym.

\section{Psychologiczne wymiary kultur: czyli o empirii w interpretacji na przykładzie Nie ma Szczygła}

W swoim reportażu Szczygieł realizuje także tezę o kulturowych skryptach zachowań społecznych. Wpływ kultury na codzienne, rutynowe zachowanie jest niemal oczywisty, bo, jak twierdzi Boski, „skrypty kulturowe to scenariusze sytuacyjne oraz wkomponowane w nie wzorce interakcji jednostek i ich wzajemnych oczekiwań, normatywnie sankcjonowane i powszechnie przyjęte w danej kulturze" (Boski, 2010: 41; Boski, van de Vijver, Hurme, Miluska, 1999: 133). Jednocześnie są one bardzo trudne do uchwycenia, bo będąc zanurzonym we własnej kulturze, badacz niejako ulega ślepocie kulturowej (Boski, 2010: 44). W związku z tym wykorzystanie w analizie literaturoznawczej narzędzi takich, jak model Wielkiej Piątki Geerta Hofstede, jego rozwiniętej, nowszej wersji funkcjonującej pod nazwą Projekt GLOBE, oraz wypracowanej przez Pawła Boskiego Skali HUMAT² pomaga w objęciu w ramy teoretyczne zagadnień tak płynnych, jak ludzka tożsamość kulturowa. Pionier tego typu działań, czyli Hofstede, próbuje bowiem przekonać, że istnieje pięć wymiarów, dzięki

\footnotetext{
2 Skala HUMAT to Skala Humanizmu-Materializmu opracowana przez Pawła Boskiego w trakcie badań, w których udział wzięli Polacy i Amerykanie żyjący w swoich krajach macierzystych oraz polscy emigranci i przedstawiciele drugiego i trzeciego pokolenia Polonii w Kanadzie i w USA (Boski, 2010: 384-385).
} 
którym można opisać kulturę (Boski, 2010: 125). Nie da się, co oczywiste, wyzbyć przemycania indywidualnych sądów przy prowadzeniu badań, zwłaszcza zorientowanych na interpretację (Boski, 2010: 125), jednak można założyć, że poziom zjawisk społeczno-kulturowych (odbijających się także w literaturze) mieści się pomiędzy bytem realnym a ideałem w strefie preferencji i postulatów, czy też pomiędzy poziomem ja realnego a ja idealnego (Boski, 2010: 129). Tak oto Hofstede opisuje kulturę przy pomocy pięciu wymiarów: dystansu władzy, hierarchiczności (Power Distance Index), indywidualizmu - kolektywizmu (Individualism), męskości-kobiecości (Masculinity), unikania niepewności (Uncertainity Avoidnace Index) oraz orientacji czasowej odległej-bliskiej (Long Term Orientation). Projekt GLOBE z kolei rozszerza tę klasyfikację do trzech triad, w obrębie których na pierwszą składają się wymiary jakości wykonania, orientacji przyszłościowej oraz unikanie niepewności; na drugą - wymiary dystansu władzy, kolektywizmu i indywidualizmu, zaś na trzecią - równość płci, asertywność oraz orientacja humanistyczna. Skala HUMAT informuje zaś o tym, że wartości humanistyczne, takie jak pozytywne i prospołeczne ustosunkowanie do innych ludzi oraz jednoczesne odejście od działań mających na celu podwyższenie statusu materialnego są jednym z ważniejszych psychologicznych wymiarów polskiej kultury, jako skrypt realizowanym w literaturze i reportażu.

$\mathrm{Na}$ wybranych do analizy przykładach z reportażu Nie ma pokazane więc zostanie, jak przy pomocy tychże właśnie empirycznych narzędzi można opisać praktyki literackie, stanowiące zwierciadło ludzkich myśli i uczuć, objętych wspólną kategorią polskiej tożsamości kulturowej. Pierwszym takim przykładem kulturowych ram zachowań społecznych jest fragment pod tytułem Kompot przed końcem świata. Na potrzeby artykułu przytoczony zostanie jedynie jego fragment, który został wyselekcjonowany do pracy z obcokrajowcami na zajęciach z języka polskiego jako języka obcego:

[...] Myśl o końcu świata zaczęła go kokietować dwa lata temu [...].

Na tyle dawno, że dziś - 4 grudnia 2012 roku - ma już zlikwidowane wszystko, co można było zlikwidować. Sprzedał mieszkanie (mieć pieniądze przed końcem!) i pozbył się wszystkich niepotrzebnych rzeczy (być wolnym przed końcem!). [...] Likwidację zaczął latem, myślał: w miesiąc się wyrobię, do grudnia jest sporo czasu. Ale kiedy brał do ręki każdą książkę, każde zdjęcie, każdy ciuch, każdy kubek, każdą widokówkę - myślenie o tym, co to za przedmiot, jakie emocje 
budzi, co z nim zrobić, czy na śmietnik, czy dać komuś, czy zachować w zestawie do przeżycia, trwało bardzo długo.

Najpierw o jednym przedmiocie rozmyślał do dziesięciu minut. Szybko jednak uświadomił sobie, że nie zdąży przed końcem, i musiał myślenie przyspieszyć. Otulał więc każdy przedmiot miłym wspomnieniem jak watą, ale tylko na pięć-dziesięć sekund, po czym watę odrywał, nawet jeśli ciężko się odklejała, i decydował.

Zbliżał się termin przekazania mieszkania nowej właścicielce, wielu rzeczy nie zdążył sprzedać, zaczął więc rozdawnictwo. Ponieważ w jego otoczeniu nikt kończyć świata nie zamierzał, ludzie chętnie wszystko brali.

Futro mamy dał sąsiadce. Kiedy mama zmarła, chciał uszyć sobie z niego kamizelkę zimową, taką przy ciele, żeby być bliżej mamy, ale tego nie zrobił. Lodówkę dał synowi sąsiadki.

Kwiaty doniczkowe, kilka pięknych okazów, zostawił nowej właścicielce mieszkania. Ktoś mu kiedyś poradził, że jeśli nie może się zaprzyjaźnić z ludźmi, powinien zacząć od kwiatów. Zaczynał od jednej doniczki, skończył na czternastu. Relacje z roślinami nie okazały się łatwiejsze od tych z ludźmi. Pierwszy kwiat mu zmarniał. Drugi mu wiądł dwadzieścia razy. Inne gniły, bo z dobroci serca lał im za dużo wody. [...]

Pozbył się swojego kożucha, bo założył, że koniec będzie bardzo gorący. Przez co dziś, choć jest minus jeden, on chodzi w palcie wiosennym. Zostało już naprawdę niewiele dni, nie wychodzi za dużo na ulicę, więc ma nadzieję, że się nie przeziębi. Ewentualnie pod wiosenne palto wkłada gruby sweter. Kończenie świata z grypą byłoby niepraktyczne, a nawet jakoś poniżające.

Kurtki, spodnie, marynarki, swetry, koszule, płaszcze upchnął w plastikowe worki, a te wcisnął do pojemników PCK*.

Książki - kto chciał, to brał [...]. Meble połamał wynajęty człowiek. [...]

Musiał jednak wziąć pod uwagę, że koniec świata nie nastąpi albo że może częściowo się nie udać. Przygotował więc zestaw do przeżycia. Zestaw niezbędnych rzeczy, które pozwolą mu dalej być sobą. Podejrzewa, że gdyby ich nie miał, mógłby być każdym, w najlepszym przypadku byłby połową siebie. [...]

Zostawił sobie podręcznik Pieleggniarstwo ogóle, który napisała jego mama. Zostawił trzy listy, jakie napisał do ojca, którego nigdy nie poznał [...]. Zostawił zeszyt od polskiego jednego ze swoich uczniów. Był wtedy po raz pierwszy wychowawcą klasy, piątej. [...] Zostawił egzemplarz „Wiadomości Literackich”, gdzie był sekretarzem redakcji - jedyny, jak mówi, numer z jego tekstem na pierwszej stronie. [...] Zostawił dwadzieścia dziewięć albumów fotograficznych na lakierowanym papierze, które wydawał po każdej ze swoich podróży. [...] Zostawił sto stron niedokończonej książki, którą zaczął pisać dwadzieścia pięć lat temu [...]. Zostawił 
libretto opery Król Maciuś Pierwszy według Korczaka. [...] Zostawił sześć tomów W poszukiwaniu straconego czasu Prousta [...].

Myślę, że zestaw do przeżycia pozwoli mu się upewnić, że istniał, istnieje i że może istnieć nadal w stary, sprawdzony sposób [...].

O końcu świata 21 grudnia wszyscy mówią z pobłażaniem. Dla niego te przygotowania to czas prawdziwego życia. Może najważniejszy. Mówi, że przestał być powolny. [...]

Wstaje z kanapy. Mam zrobić kolację, idziemy więc do kuchni. Widzi na blacie stos małych i nadpsutych jabłek. Żartuję, że zrobię im koniec świata i zaraz je wyrzucę, bo zaczynają gnić. A on na to, że mi je obierze. Można ugotować kompot, wystarczy dodać cukru i jednego goździka. Łapie nóż, obiera, nadaje im drugie życie. Może dlatego przy jabłkach dochodzimy do najważniejszego.

- Bo po każdym końcu świata - tłumaczy - musi być jakiś początek [...]. Potem zrozumiałem, że aby coś otworzyć, coś trzeba zamknąć.

(Szczygieł, 2018: 136-148).

Wyjaśnienia wymaga motywacja wyboru powyższego fragmentu. Kluczowe dla analizy zorientowanej na psychologię międzykulturową jest to, że wybrany fragment obrazuje doświadczenie człowieka postawionego wobec sytuacji kryzysowej. Jest to zatem sytuacja, która dotyczy każdego (koniec świata 2012 roku dotyczył społeczności globalnej, a zachowania wobec tej nowiny, jak się zdaje, zależne były od kultury). Prowokuje to do osadzenia tekstu w kontekście kulturowym, a co za tym idzie, do zderzeń interkulturowych, polegających na porównywania kultury własnego kraju z kulturą Polski. Tym samym zmusza to do krytycznej i wielowymiarowej interpretacji, w której człowiek jest zarówno jednostką, jak i członkiem określonej społeczności. Wybrany do analizy fragment pozwala na aranżowanie autentycznych sytuacji, a przez to uwrażliwia czytającego na określone role społeczne, umożliwiając zarazem wejście w dialog międzykulturowy przez porównanie tego, co czytający już zna, z tym, co dlań nowe. Bohater fragmentu jawi się bowiem jako psychologiczny model przedstawiciela kultury polskiej. Jego zachowanie, polegające między innymi na segregowaniu rzeczy materialnych, wpisuje się w opozycję humanizmu i materializmu jako trzonowego wymiaru polskiej kultury. Przechowywanie kożucha i innych pamiątek o wartości sentymentalnej w skali HUMAT mieści się w ramach punktów Utrzymywanie i pielegnowanie dtugoletnich, serdecznych przyjaźni oraz silna rodzina. Przechowywanie rzeczy, które w rzeczonej skali 
(w odniesieniu do Polaków) wiąże się z negatywnym obrazem świata materialnego, w tym wypadku jest sprowadzone do wartości humanistycznej, bo owe przedmioty pozwalają na zatrzymanie pamięci. Humanizm jawi się tym samym jako ważny dla jednostki obszar wartości i celów życiowych (Boski, 2010: 386). Choć postać pozbywa się rzeczy, które są dla niej obciążeniem (związek z negatywnym postrzeganiem materializmu), to jednocześnie swoją postawą pokazuje, że przechowywanie może być pozytywnym wymiarem polskiej kultury, zorientowanym na humanizm. Pamiątki, które zachowuje, są bowiem dla bohatera częścią ideału kulturowego w obrębie wartości humanistycznych (Boski, 2010: 386). Pozbycie się mieszkania oraz uargumentowanie tego zachowania świadczy także o tym, że, „w Polsce nie doszło do kulturowego przyzwolenia na bogacenie się" (Boski, 2010: 386). Wpisuje się to w spolaryzowanie kultury polskiej na pozytywną część humanistyczną oraz negatywnie widziany świat wartości materialnych, co doprowadza do pęknięcia na obszar akceptacji i odrzucenia (Boski, 2010: 386). Ten wymiar jest charakterystyczny także dla innych kultur narodowych, na przykład dla Czech, których opisywaniem zajmuje się Szczygieł także. Przykładem tego jest inny fragment Nie ma, zatytułowany Gwiazda wszystkich willi, realizujący temat losów rodziny Milady i Frantiska Mullerów:

Piękno nie jest dane raz na zawsze. A kto pragnie go tylko dla siebie, nawet jeśli sam za nie zapłacił, będzie ukarany. Milada i František Müllerowie chyba tego nie przewidzieli.

(Szczygieł, 2018, 203)

Willa od początku swego istnienia budziła spore zainteresowanie wśród mieszkańców Pragi, którzy sekundowali marzeniu Müllerów o „pięknym życiu” (Szczygieł: 211), jednak wyżej przywołany komentarz reportera jasno wskazuje, że dom, będąc zrazu wartością materialną, wymyka się poza aprobowane w społeczeństwie pozytywne wartości humanistyczne. Bogacenie się jest bowiem negatywnie odbierane, nawet jeżeli pozornie jest aprobowane. W tym więc kontekście tytuł całego zbioru reportaży - Nie ma - oznaczać może nie tylko „braki”, które towarzyszą człowiekowi, lecz także nastawienie antymaterialistyczne. Skoro bowiem nic nie jest dane raz na zawsze, to nie ma też przyzwolenia na przywiązywanie się do osób i miejsc czy też przedmiotów.

Interpretację tę potwierdzają operacje językowe na tekście przeprowadzone wraz ze studentami-obcokrajowcami podczas lekcji języka polskiego 
jako obcego. Oto bowiem odpowiedzi na pytania wstępne ${ }^{3}$ oraz zadania wykonane po lekturze ${ }^{4}$ pokazały, jak różne podejście do określonych sytuacji reprezentują przedstawiciele różnych kultur i jak bardzo zmienia się owo podejście w wyniku spotkania z literaturą prezentującą nowe wzorce. W swoich analizach i interpretacjach obcokrajowcy „nałożyli” na tekst własną kulturę i własne doświadczenia. Moderowanie dyskusji przez nauczyciela uwrażliwiło ich z kolei na przyjęcie perspektywy otwartości na „nowe” i wzmocniło tym samym ich wrażliwość interkulturową. Po pierwsze bowiem, udzielając odpowiedzi na pytania wstępne, uczący się odwoływali się do tekstów kultury im znanych, a także do różnej popkulturowej realizacji wariantów końca świata. Po drugie, w zadaniu po lekturze tekstu wykazywali charakterystyczne dla ich kultury realizacje psychologicznych wymiarów ich funkcjonowania. I tak na przykład wytypowani do zadania improwizacji rozmowy dziennikarzy dwaj Hindusi w swoich wypowiedziach zrealizowali charakterystycznych dla ich kręgu kulturowego wzorzec dystansu władzy ukierunkowany na tzw. gerontokrację, czyli szczególne poszanowanie i oddawanie głębokiego szacunku osobom starszym. Ich wypowiedź zasadziła się bowiem na schemacie, w którym poszanowany ekspert, z wieloletnim doświadczeniem wypowiada się na temat dowodów na istnienie końca świata, zaś dziennikarz z aprobatą przyjmuje za pewnik wypowiadane przez doświadczonego eksperta sądy. Ukraińcy, uczący się języka polskiego w tej samej grupie, realizując rolę dwójki ludzi, którzy o końcu świata dowiedzieli się na dworcu kolejowym, wykazali z kolei nieufność wobec

3 Jakie historie związane z końcem świata Pani/Pan zna? oraz Czy pamięta Pani/Pan doniesienia na temat końca świata 2012 roku? Jeśli tak, proszę powiedzieć, jak się Pani/Pan do tego odnosił? Proszę powiedzieć także, co się wtedy działo w Pani/Pana kraju w tym czasie? 4 Proszę sobie wyobrazić, że za trzy miesiące nastąpi koniec świata w wyniku zderzenia Ziemi z ogromna asteroidą, i dowiadują się Państwo o tym z informacji radiowej. Proszę wcielić się w następujące role: a) Dwaj dziennikarze prowadzący audycję: proszę przekazać informację o końcu świata w postaci komunikatu radiowego [komunikat powinien zawierać informacje, kiedy nastąpi koniec świata, w jakich okolicznościach, jak można się uchronić itp.]; b) Młode małżeństwo, które właśnie usłyszało ten komunikat w samochodzie: proszę zaimprowizować ich reakcję na tę wiadomość; c) Emeryt, który właśnie usłyszał tę informację w swoim domu: proszę zaimprowizować jego reakcję na tę wiadomość; d) Ludzie na dworcu kolejowym, którzy usłyszeli tę informację: proszę zaimprowizować ich reakcję; e) Dwie osoby, które rozmawiają przez telefon, i jedna z nich usłyszała tę informację w radiu: proszę zaimprowizować ich rozmowę i reakcję. 
zasłyszanych komunikatów oraz kwestionowanie zasadności przygotowywania się do końca świata. Inny Ukrainiec, który wszedł w rolę emeryta, skupił się zaś na fakcie odnowienia relacji rodzinnych oraz materialnego zabezpieczenia rodziny w razie, gdyby koniec świata miałby się nie udać.

Fragment Kompot przed końcem świata wyraźnie wpisuje się także w działania analityczno-interpretacyjne z wykorzystaniem psychologicznych wymiarów kultur Hofstedego oraz projektu GLOBE. Pozostawienie przez bohatera pamiątek to, jak już zaznaczono, podtrzymywanie i pielęgnowanie silnych związków rodzinnych, które w modelu Wielkiej Piątki mieszczą się w punkcie „indywidualizm - kolektywizm”. Zestaw przeżycia, który bohater pozostawia sobie, pozwala mu bowiem „upewnić się, że istniał, istnieje i że może istnieć nadal w stary, sprawdzony sposób”. To wpisuje się zaś w typowo polski kolektywny model społeczeństwa, który zakłada, że „jednostki od urodzenia przez całe swoje życie są zintegrowane z silnymi, spójnymi grupami Swoich, które to grupy zapewniają na stałe ochronę w zamian za bezwarunkową lojalność" (Hofstede 2001:225). Choć bohater mieszka sam, to jednak przedmioty, do których jest przywiązany, i które otula wspomnieniami, przypominają mu o rodzinie i przyjaciołach zapewniających ochronę. Ta ochrona wiąże się jednak także z innym psychologicznym wymiarem kultury, mianowicie z puntem „unikanie niepewności”. Bohater fragmentu próbuje bowiem w sytuacji nadchodzącego końca świata po pierwsze, ocalić pamięć zaklętą w przedmiotach (ocalenie pewnej przeszłości), po drugie zaś, przygotowuje zestaw przeżycia, który ma uchronić go przed niepewnością. Bohater dąży zatem do zredukowania pełnej nieprzewidywalności przyszłości (Boski, 2010: 108-109). Bohater tym samym stara się uniknąć niepewności, wykazując zarazem potrzebę domknięcia poznawczego i zaplanowania własnego życia. Jego zachowanie wskazuje także na potrzebę unikania improwizacji, gdyż zwraca uwagę na to, że koniec świata może nie nastąpić. Unikanie niepewności jest bowiem definiowane jako „stopień zagrożenia, jaki członkowie danej kultury odczuwają w związku z niepewnymi lub nieznanymi im sytuacjami” (Hofstede: 161). 


\section{Podsumowanie}

Inspiracją do napisania niniejszego teksu stały się prowadzone przeze mnie zajęcia z zakresu języka polskiego jako obcego, podczas których wykorzystałam fragment reportażu Kompot przed końcem świata, wchodzącego w skład książki Mariusza Szczygła pod tytułem Nie ma. W fazie przygotowawczej założyłam, że wybrany do analizy tekst poszerzy wiedzę interkulturową moich studentów (pozwoli im dostrzec podobieństwa i różnice między kulturą własną a polską w odniesieniu do refleksji zawartych w tekście literackim) oraz umożliwi im poznanie realiów socjokulturowych ułatwiających funkcjonowanie w Polsce. Analiza i interpretacja reportażu z wykorzystaniem założeń psychologii międzykulturowej ugruntowały te założenia. Przedstawione tezy uzmysłowiły jednocześnie, że tego typu podejście może stać się ciekawą drogą metodologiczną w badaniach literaturoznawczych zorientowanych na interdyscyplinarność. Mnie jako badacza utwierdziły zaś w przekonaniu, że sfera hermeneutycznego doświadczenia w połączeniu z filologicznym podejściem do tekstu prowadzi do odszyfrowania sensu przekazu literackiego. Analiza teksu literackiego oparta na założeniach psychologii międzykulturowej skłania bowiem nauczycieli języka polskiego oraz badaczy literatury do tego, by poszukiwać odpowiedzi na pytania o tożsamość kulturową. Przyjęcie tej perspektywy, jak sądzę, pozwala także na to, by lepiej sobie radzić w świecie, w którym sieć światowych połączeń w perspektywie globalnej gęstnieje i intensyfikuje się. Umożliwia to zarówno uczącym się języka, jak i uczestnikom danej kultury (w tym wypadku polskiej) zrozumienie siebie i obcego. Dzięki takiemu czytaniu jesteśmy w stanie lepiej zrozumieć samych siebie, a tym samym lepiej tłumaczyć specyfikę polskiej kultury i literatury przedstawicielom innej kultury (Boski, 2010: 372). Reportaż Nie ma, choć w niniejszym artykule analizowany w kilku reprezentatywnych fragmentach, jawi się nie tylko jako opowieść o braku, który wraz z jego uświadomieniem sobie otwiera na świat i wskazuje rytmikę życia (Szczygieł: 309), lecz także jako obraz stosunków międzyludzkich, swoiste studium budowania autodefinicji człowieka, stykającego się z szokującymi i twórczymi zarazem doświadczeniami. 


\section{Bibliografia}

Abrams, Mayer Howard. Zwierciadto i lampa. Romantyczna teoria poezji a tradycja krytycznoliteracka. Tłum. Maria Bożena Fedowicz. Gdańsk: Słowo/obraz terytoria, 2003.

Benedict, Ruth. Wzory kultury. Tłum. Jerzy Prokopiuk. Warszawa: Wydawnictwo Naukowe PWN, 1966.

Blumenberg, Hans. Praca nad mitem. Tłum. Kamilla Najdek, Michał Herer, Zbigniew Zwoliński. Warszawa: Oficyna Naukowa, 2009.

-----. Paradygmaty dla metaforologii. Tłum. Bogdan Baran. Warszawa: Wydawnictwo Aletheia, 2017.

Boski, Paweł. Kulturowe ramy zachowań spotecznych. Podręcznik psychologii międzykulturowej. Warszawa: Wydawnictwo Naukowe PWN, 2010.

------, Fons van de Vijver, Helena Hurme, Jolanta Miluska. „Skrypty kulturowe zachowań w rolach płciowych: Jak interakcje Polaków i Polek są odbierane w kraju i za granicą?”. Męskość-kobiecość w perspektywie indywidualnej i kulturowej. Red. Paweł Boski, Jolanta Mikulska. Warszawa: Instytut Psychologii PAN, 1999. 112-142.

Czerkies, Tamara. Tekst literacki w nauczaniu jezyka polskiego jako obcego (z elementami pedagogiki dyskursywnej). Kraków: Księgarnia Akademicka, 2012.

-----. „Wstęp”. Tejże. Literackie lustro kultury. Literatura polska w ćwiczeniach dla obcokrajowców. Kraków: Wydawnictwo Avalon, 2019: 7-9.

Fairclough, Norman. Critical Discourse Analysis. The Critical Study of Language. London-New York: Pearson Education, 1995.

Goodman, Kenneth. „The Psycholinguistic Nature of the Reading Process”. The Psycholinguistic Nature of the Reading Process. Red. Kenneth Goodman. Detroit: Wayne State University Press, 1968.

Hofstede, Geert. Culture's Consequences: Comparing Values, Behaviors, Institutions, and Organizations Across Nations. Thousand Oaks, CA: Sage, 2001.

Jarymowicz, Maria. „Tożsamość jako efekt rozpoznawania siebie wśród swoich i obcych”. Paweł Boski, Maria Jarymowicz, Hanna Malewska-Peyre. Tożsamość a odmienność kulturowa. Warszawa: Instytut Psychologii PAN, 1992. 213-275.

Kapuściński, Ryszard. Podróże z Herodotem. Kraków: Znak, 2004.

Kłoskowska, Antonina. Kultury narodowe u korzeni. Warszawa: Wydawnictwo Naukowe PWN, 1996. 
Markowski, Michał Paweł. „Zwrot etyczny w badaniach literackich”. Pamiętnik Literacki 1 (2000): 239-244.

Montgomery, Martin i in. The Ways of Reading. Advanced Reading Skills for Students of English Literature. London: Routledge, 1992.

Pankalla, Andrzej Bronisław, Konrad Kazimierz Kośnik. Indygeniczna psychologia Stowian. Kraków: Universitas, 2018.

Rorty, Richard. „Zmierzch prawdy ostatecznej a narodziny kultury literackiej”. Tłum. Andrzej Szahaj. Teksty Drugie 6 (2006): 113-130.

Steiner, Georg. Gramatyki tworzenia. Tłum. Jerzy Łoziński. Poznań: Zysk i S-ka, 2004.

Szczygieł, Mariusz. Nie ma. Warszawa: Dowody na istnienie, 2018.

Wierzbicka, Anna. Jezzyk-umyst-kultura. Warszawa: Wydawnictwo Naukowe PWN, 1999.

-----. Semantyka. Jednostki elementarne i uniwersalne. Lublin: Wydawnictwo Uniwersytetu Marii Curie-Skłodowskiej, 2006.

\title{
The Cultural Frames of Social Behavior in Mariusz Szczygieł's Reportage Nie ma (the Intercultural Psychology in Literary Studies)
}

\begin{abstract}
Summary
The subject of the article is the cultural frames of social behavior in Mariusz Szczygiel's reportage Nie ma. I use the assumptions of intercultural psychology to analyze the reportage text. The adopted methodology results from the feeling that in the era of intensified contacts with representatives of various cultures, the researcher is forced to search for answers to questions about the cultural identity of Poles, manifesting themselves both in specific social behaviors and in literature. Intercultural psychology makes this task easier, because it makes us aware of the fact that literature is a mirror in which everyone who consciously enters a new culture looks.
\end{abstract}

Keywords: intercultural psychology, literature, reportage

Słowa kluczowe: psychologia międzykulturowa, literatura, reportaż 